\title{
Innovation and reform of enterprises in the era of Internet -- Based on the research of real estate industry
}

\author{
Shuwen Ren \\ Business school, Sichuan University, Chengdu 610000, China \\ Chrissren02@hotmail.com
}

\begin{abstract}
China's economy is in the conversion process. The real estate industry has to understand and embrace the Internet from the new phase. The core of the real estate industry is changing, the market demand is shifted from the traditional residential level demand to a higher level of life demand. And the Internet can change the way of information acquisition and communication, the aggregation and integration of effective demand information. In this essay, through the analysis of the impacts of the Internet to the real estate industry, the Internet has changed the consumption trend, the key link of marketing and consumer demand. The internal problems and external pressure promote the traditional real estate companies to transform in order to maintain and enhance competitiveness. According to the real estate enterprise internal and external condition, the article puts forward two major directions: to change the marketing approach and to improve the management and cross-border diversified layout.
\end{abstract}

Keywords: Internet; real estate industry; marketing; property management.

\section{Introduction}

While real estate still maintains its important position in economic, its bottleneck is also obvious. Recently, after decades of savage growth, it is experiencing industry adjustment period. It can not make money only by land appreciation and high leverage anymore. Therefore, the vast majority of enterprises are in a critical period of breakthrough, upgrading and transformation. The external pressure and internal power are both strong. The year 2015 is not a prominent year for real estate industry, but it is the first year of its transformation and internet innovation. March 2015, in the NPC and CPPCC, National People's Congress Ma Huateng submitted the proposal about "Internet+". In the same month, Premier Li Keqiang put forward the "Internet +" plan in the government report for the first time, aiming at developing "Internet+" plan and promoting the combination of mobile Internet, cloud computing, big data, networking and other modern manufacturing industry. After this, the real estate industry's internet marketing is becoming intensive.

In the existing literature, the research on impact of the Internet on the real estate industry and the strategic transformation of real estate industry in the era of the Internet is very limited. Considering the importance of real estate industry in the national economic development and importance of the Internet's growth, it needs further research in this domain. At the same time, the current practices for real estate enterprises in "Internet +" concentrate on marketing or other single link. In this way, this article hopes to explore more transition areas for the real estate industry in the Internet era. Through literature analysis and case study method, this article discusses the subject of transformation of real estate enterprise in the Internet era.

Through the analysis of the impacts of the Internet to the real estate industry, the Internet has changed the consumption trend, the key link of marketing and consumer demand. These changes fundamentally changed the external survival environment for real estate business. In addition, there are problems that real estate industry are facing, which include the raising cost of land, the changed demand structure, the differentiation performance of different cities and other development bottlenecks. These internal problems and external pressure promote the traditional real estate companies to transform in order to maintain and enhance competitiveness. The author puts forward two major directions: to change the marketing approach, to improve the property management and cross-border diversified layout. 


\section{The first direction: Marketing}

Since March 2015 the National People's Congress and the Chinese Political Consultative Conference ( NPC \& CPPCC ), Internet + concept was written into the government report, internet marketing intensified in the real estate industry. In addition to overweight to push the quantity, the adjustment of product structure, the enterprises frequently touch the Internet marketing. The aim is to find new selling points, broaden the channels, mine source and find new patterns. Internet marketing is increasingly popular among real estate industry.

The background of real estate is that the profit margins is narrowed and the industry has to find another way. With the concept of Internet + , the industry once again want to find a breakthrough point in the marketing link. They make the use of Internet technology to promote products, and found the need online, so as to achieve the purpose of selling products. Throughout this year's housing enterprises marketing cases, the marketing link has been very closely related to the internet. Compared to 2014, since the beginning of this year, the price competition in this industry is rare.

At the same time, under the pressure of performance improvement, the industry wants to seek change in the marketing strategy. In order to find innovative selling points and get through various marketing channels, Internet + innovative marketing approach has become the first choice to some companies. On the one hand, poly, Biguiyuan, and some other companies are using mobile Internet platform to make marketing promotion. On the other hand, Fangxing is selling houses in Taobao. 18 enterprises jointly organized "Wechat Purchase Festival". To make use of the electronic business platform, the real estate not only can make integration of products and resources, broaden the source, but also open up the online and offline channels, implementation of online transactions. Such action pushes Internet marketing another climax.

It is not difficult to find that the Internet + marketing in the industry has begun to take the right track and is expected to go up in the future. In the next period, in order to respond to industry changes, especially in the face of growing dependence of consumer demand groups on the Internet, the industry will continue to use the Internet in the marketing level. Marketing combined with the Internet will become new normal in the industry.

One reason to make use of internet in marketing is that the internet improves sales efficiency. To make use of Internet mode in marketing links has two effects. on the one hand, it enlarges the channel effect of the Internet. It achieves a wide range of information dissemination and low cost marketing extension. On the one hand, it helps to found the demand, customized precision marketing from the intention of the customer level. The rise of the Internet, and the Internet combined with the promotion has got a wide attention in the industry. so far, the Internet + marketing has experienced three stages from simply spreading information to the efficient extension of the customized marketing. Such three stages, advanced Internet + real estate enterprises in marketing process.

The first stage is to make the use of the Internet platform to promote marketing information quickly spread. The Internet and the industry has been linked. The traditional paper media, electronic media are getting left out, along with the rise of online advertising. Nowadays, as an efficient platform for information dissemination, the Internet is still playing a cornerstone role in the housing enterprises marketing. In addition, the appearance of mobile Internet accelerated efforts of information dissemination and breadth. For example, micro blog, Wechat can get attention from customers to keep abreast of trends in the industry. It can also become enterprises marketing exclusive platform.

The second stage is that the Internet achieve the connection in the human as a valid extension tool. In the second stage, the Internet + marketing has the value of interpersonal relationship to the real industry. It can become a tool to spread information to a specific group of people, and then be spread by this part of the people, and guide more customers. It can also achieve cooperation with the Internet platform. The two sides can transform their customers, such as cross-border E- suppliers.

The third phase is that it can provide solutions based on customer feedback, which is the highest expression of the Internet thinking. On the one hand, Internet helps the industry approach the customers. On the other hand, it finds a shortcut for the industry to find the customer needs. 
Compared to the first stage of pure communication information, the second phase of the maximum convene of customers, the third stage takes the customized route. The aim of marketing is not looking for customers. The customer is always there. In the third stage, the Internet + marketing return to customers. It provides solutions based on customer needs. This marketing strategy is the source of real estate industry marketing.

\section{Direction two: Property management}

In the year of 2014, no matter it is a traditional enterprise or Internet Company, and even some individuals newly established small companies, are advertising themselves to seize the last mile of community services. The 'community' also become one of the year's most popular vocabulary. Through the Internet connection line, the service platform makes providing service to residents as a starting point, makes the use of internet.

The first background of the development of property management is that the commercial property is oversupplied and there is favorable policies to promote its development. Since 2010's house purchase restriction, many enterprises rely on the sale of the commercial property to achieve rapid growth in business. However, such course of action also makes a significant oversupply of commercial real estate in some of the cities or regions. In addition, in the era of explosive development of electricity suppliers, the traditional business model has been seriously impacted and the rental has become a major concern of the industry.

The second background of such trend is the national introduction of favorable entrepreneurial policies. The emerging entrepreneurial team lead to new office needs. Recently, the state has introduced policies to support entrepreneurship. March 2015, the general office of the State Council issued the guidance on the development of the public to create space to promote public innovation and entrepreneurship, and promote public entrepreneurship. Then, in April, the State Council put forward actions to promote the creation of space and other incubators and public space and tax incentives to encourage entrepreneurship. Once again the country refines the implementation of policies to support the public space of creation. Good policies Supports for entrepreneurship continue emerge, which provides a good external environment for the joint office.

Property management undoubtedly has market prospects. in the short term, it can generate real profits. In the long-term, it can excavate the value of the community $\mathrm{O} 2 \mathrm{O}$. the battle of Property management industry is just currently beginning. In the future, there will be more companies join in this field. In this regard, there are following suggestions for the property management companies.

Firstly, the existing companies should seize the period of consolidation in the industry and accelerate the expansion of mergers and acquisitions. The first preference is the property project which maintenance cost is lower and loss property management companies due to poor management. Secondly, through standardization, scientific and technological means to improve the operational level of property management, including improving the standardization of services, improving the management details through information, shortening the service distance through the Internet, improving the safety of the material management through industrialization and improving the quality of personnel. Thirdly, companies should enhance community $\mathrm{O} 2 \mathrm{O}$ platform experience, including improve the user engagement and the APP user experience.

\section{Conclusion}

Nowadays, the real estate industry is facing a tough period. The companies must find ways to seize the opportunity of internet. The author recommends the internet+marketing and internet+property management models. The two models can fuse big data, mobilize and marketing, which make new development space for the real state industry. 


\section{Reference}

[1]Elliott C, Agnew C, Nickson M. Technology Europe: IT Spending Survey, Goldman Sachs Group, London 2004

[2]Fleish E,Mattern F (Hrsg.),Das Internet der Dinge-Ubiquitous Computing und RFID in der Praxis, Springer,Berlin 2005

[3]Gomolski B, Can You Survive Without Cutting Your IT Budge, Gartner Research, Stamford(CT)2001

[4]Hailstone R. Case study and returnon investment. Use of SAP netweaver at BG Group, IDC, Framingham (MA) ,2003

[5]Hodgkinson S L,The Role of the Corporate IT Function in the Federal IT Organization,in: Ear l, M. (Hrsg.),Information Management: The Organizational Dimension, Oxford University Press, 1996

[6]The mobile commerce value chain-analysis and future development, International joumal of information management, 2002(22) 